sympathetic afferent fibres or B1 receptor sites in the lung which are known to stimulate $\mathrm{ADH}$ secretion. ${ }^{3}$ The involvement of the vagus nerve by a bronchogenic carcinoma and associated inappropriate $\mathrm{ADH}$ secretion is described by Bower et al. However, they were also able to substantiate the antidiuretic activity of the tumour and postulated this and the possibility of distortion of vagal afferent impulses as a cause of inappropriate ADH secretion in their patient. The stress of the acute disease may also play a part, though the $\mathrm{ADH}$ response to stress has not been shown to be susstained. ${ }^{3}$-I am, etc.,

University Department of Medicine,

Royal Melbourne Hospital,

1 Bryant, D. H., Medical fournal of Australia, 1972, 1, 1285.
Phillips, M. E., et al., British Medical fournal, 1974, 2, 149 .

Schrier, R .W., and Berl, T., Kidney, 1974, 7, 1. Weiss, H., and Katz, S., American Review of Respiratory Diseases, 1965 .
Utz, J. P., et al., New England fournal of
Medicine, 1969, 260, 264.

6 Bower, B. F., Mason, O. N., and Forsham, 271, 934 .

\section{Hypertension and Myocardial Infarction}

SIR,-I was interested to read your recent leading article (5 January, p. 1) and the views of Dr. F. T. B. Lovegrove (4 May, p. 279), Dr. I. McD. G. Stewart (27 July, p. 251), and Dr. D. M. D. Lambert (14 September, p. 685).

Ex Africa semper aliauid novi; this statement, traditionally ascribed to the Greeks by Pliny the Elder, is applicable to hypertension and myocardial infarction in the African. While hypertension in the African is common, myocardial infarction is rare. In the urban African in Johannesburg hypertension and its complications is believed to be the second most common cause of death in the adult after violence. ${ }^{1}$ Yet myocardial infarction is rare.

In my study ${ }^{2}$ of 1,000 hypertensive patients (500 Africans and 500 Indians) who were followed up over a period of 13 years the incidence of cardiac changes is shown in the table. It will be noted that while

\begin{tabular}{l|c|c}
\hline \multicolumn{1}{c|}{ Cardiac Change } & $\begin{array}{c}\text { Africans } \\
(\%)\end{array}$ & $\begin{array}{c}\text { Indians } \\
(\%)\end{array}$ \\
\hline $\begin{array}{l}\text { E.C.G. Left ventricular } \\
\text { hypertrophy }\end{array}$ & 23 & 22 \\
$\begin{array}{l}\text { Clinical cardiomegaly } \\
\text { Ischaemia heart disease }\end{array}$ & 29 & 26 \\
Chest radiograph: left & $\mathbf{2 0}$ & 12 \\
ventricular hypertrophy & 30 & 35 \\
$\begin{array}{l}\text { Normal chest radiograph } \\
\text { Congestive heart failure }\end{array}$ & 70 & 65 \\
\hline
\end{tabular}

congestive cardiac failure due to hypertension occurred in $16 \%$ of the Africans, ischaemic heart disease did not occur. This is in contrast to the Indian population, in whom myocardial infarction or angina pectoris occurred in $12 \%$ of cases. Our hospital has 2,000 beds and serves a population of 2 million; there are approximately 800,000 patients attending the outpatient department and about 99,000 are admitted to the hospital per year (African $83 \%$, Indian $17 \%)$. While myocardial infarction is common in Indians, the number of cases of myocardial infarction or angina pectoris in Africans does not exceed 10 per year. The incidence of coronary atheroma in Africans at necropsy is far less than in the European or Indian population in Durban. ${ }^{3}$ The Framingham study ${ }^{4}$ found that increased serum lipids, hypertension, cigarette smoking, overweight, and diabetes mellitus were predisposing factors for myocardial infarction. The African has all the above predisposing factors with the exception of increased serum lipids. The rarity of myocardial infarction in the African could be because the mean serum lipids level are lower than in other races. Walker ${ }^{5}$ found that in the 30-39-year age group a serum cholesterol level above $220 \mathrm{mg} / 100 \mathrm{ml}$ was present in $55 \%$ of whites, $45 \%$ of Indians $25 \%$ of urban Bantu, and $10 \%$ of rural Bantu in South Africa; the proportion for whites was much the same as that reported in the Framingham study-namely $58 \%$ However, hypertension is not uncommonly associated with cerebral atheroma and atheroma in the aorta. In our study of 1,000 patients ${ }^{2}$ cerebrovascular episodes occurred in $5 \%$ of African and $10 \%$ of the Indian patients. We feel that a high incidence of ischaemic heart disease is related to underlying diabetes mellitus and associated hypercholesterolaemia.

Our work suggests that hypertension alone is not an important predisposing factor in the aetiology of myocardial infarction. It may be an important correlate with other factors that predispose to myocardial infarction rather than a causal factor. Similar work in Zaire $^{6}$ has shown that while hypertension is common and not uncommonly produces congestive cardiac failure, myocardial infarction does not occur.-I am, etc.,

Department of Medicine,

University of Natal,

Durban

Seftel, H. C., Medicine and Society in South Africa-Some Plain Thinking, p. 14. Johannes burg, Witwatersrand University Press, 1973 .
Seedat, Y. K., and Reddy, J., South African Medical fournal, 1974, 48, 816. t Kannel, W. B., et al., Annals of Internal Medi-
cine, 1961, 55, 33. cine, 1961, 55, 33.
Walker, A. R. P., South African Medical fournal,
1973, 47, 85.

Marcoyannopoulou-Fojas, H., Abstracts of Proceedings of
1974 . In press.

\section{Variability in Response to Drugs}

SIR,-I find it remarkable that in his survey of "Variability in Response to Drugs" (12 October, p. 91) Professor M. D. Rawlins contrived to avoid any clear acknowledgement that psyche influences soma. Is it not general experience that "rational drug therapy"-like many another logical, technical process-often fails for "irrational" reasons?

Just as important as the patient's acetylator status is his psychological status. No doubt they interact. So let us by all means estimate plasma concentrations and gain a better understanding of tissue sensitivity and dosage control. But let us also acknowledge that a man is more than a biochemical system. Many human "diseases," like epilepsy and depression, are relieved by treatment methods which may incorporate the use of drugs but also take account of a person's inner needs and outer relationships.-I am, etc.

J. K. W. MORRICE Ress

\section{Medical Management of Heartburn}

SIR,-Your leading article on this subject (12 October, p. 64) begins by stating that acid reflux causes heartburn; but alkaline reflux can cause severe heartburn also. The article goes on to mention the variable and largely unpredictable response to alkalis and other remedies and discusses a number of more scientific forms of treatment based on recent research. A very curious statement is that "attempts to improve general muscle tone should strengthen the oesophageal sphincter." There is surely no evidence for this whatever, and it is a matter of common observation that many with otherwise excellent health and good muscle tone suffer from heartburn.

My main criticism is, however, that no mention is made of the fundamental reasons for the prevalence of heartburn-an incompetent sphincter and its associated condition, sliding hiatus hernia. These conditions are a feature of western civilization with its tendency to overeat. It may be that the character of the diet, with a high proportion of refined carbohydrate, leads to disorders of gastric secretion and gastrooesophageal motility; but a simple remedy for heartburn and reflux (in the absence of gross anatomical disorders at the oesophagogastric junction such as hiatus hernia) is to avoid eating unless appetite is present, as has been emphasized by Cleave. ${ }^{1}$ The eating of meals as a matter of social habit rather than necessity is the cause of much heartburn, and it is not necessary to invoke complex pharmacology for its diagnosis or treatment.-I am, etc.,

Diss, Norfolk

KenNeth S. Mullard

1 Cleave, T. L., The Saccharine Disease, p. 176 Bristol, Wright, 1974.

\section{Anonymous Appointments}

SIR,-The expansion of hospital bureaucracy is nowhere better illustrated than in the much-read appointments pages of your journal. It is frequently necessary to read the whole of a box of small print to discover at which hospital a post will be held. Occasionally this is only hinted at by the address of the personnel officer. In no such case is the name of the group hospital management committee left in doubt. This is less important information to a doctor than the name of the place where he will live and work. It could be appended or even omitted.-I am, etc.,

London S.E.1

M. PRENDERgast

Economies in the N.H.S.

SIR,-The joint letter from certain doctors at the Royal United Hospital, Bath (12 October, p. 109), while showing a commendable concern for economy in the National Health Service, unfortunately does not show the same concern for accuracy in terminology or convey a corrrect interpretation of Department of Health requirements regarding the provision of sterile water for operating theatre use.

The Department of Health has not specified that sterile topical water for use in operating theatres should be particle-free but has indicated that it should be freshly 